\title{
Ramanuja on Time
}

\author{
Marcus Schmucker \\ Institute for the Cultural and Intellectual History of Asia \\ Austrian Academy of Sciences \\ Vienna, Austria \\ E-mail: marcus.schmuecker@oeaw.ac.at
}

\begin{abstract}
In an investigation on how time was introduced into the system of Ramanuja, the author focuses on his refutation of the Jaina concept of time in his commentary on Brahmasutra 2.2.31. Starting with an outline of the opponent's arguments regarding whether time is substance or a specific state, the paper shows how Ramanuja criticizes the idea that one state is simultaneously present, and others are not. This is the basis he used to refute the Jaina concept of time, whereupon he introduces his own doctrine in just a few sentences. The tradition after Ramanuja tentatively interprets Ramanuja as positing time as a substance, without totally dismissing the possibility that he accepts time as a specifier of other categories.
\end{abstract}

Keywords-time; substance; specifier; difference; identity; existence; non-existence

\section{INTRODUCTION}

While the aspect of time (kāla) in the theistic tradition of Viśsistāâdvaita Vedānta has rarely ${ }^{1}$ been considered, it nevertheless was an important topic in the later development of the tradition, which examined whether time should be defined as an independent substance (dravya) or as a quality (viśeșaṇa) [1]

A first concept of time was expressed prior to Rāmānuja by Nāthamuni in his Nyāyatattva, where it is stated that time can only be an external factor, i.e. an adventitious limiting condition (upādhi). For him time is defined as "the number of action depending upon the same substratum" 2 . But Nāthamuni's view was not generally accepted and in works by Rāmānuja, no reference is found to Nāthamuni's statements on time. Rāmānuja does give, however, a short explanation of time in the context of his refutation of the Jaina view on time as atomic (anu). The understanding of time then changes in the work of Venkatanātha (1268-1369) and is developed in the work of Meghanādārisūri (12th century), two famous successors of Rāmānuja. The latter devotes an independent chapter to time in his Nayadyumani

Lakshmithathachar summarizes in his article Concept of Time from the Point of View of Visistââadvaita-Vedānta "Since time is one of the sub-divisions of the insentient beings, it is also a mode of the Supreme Brahman which acts as the instrumental cause of creation. Embodied with this time, the Supreme Brahman creates the universe. [... ] The primordial matter gets transformed into various objects in this world by the will of Parabrahman at the appropriate time."

ekāśrayakriyāsañkhyā kālaḥ eñkira nyāyatattvagranthattukkum kālopādhisvarūpam collukaiyilē tātparyam. entitled kālanirūpana, i.e. the "definition of time", and the former deals with time quite often in shorter or longer passages in several of his Sanskrit and Maṇipravāla works. ${ }^{3}$ Not only is the concept of time different between them, but also their interpretation of Rāmānuja's explanation is different and even controversial. In the further development of theological and philosophical concepts in the work of both thinkers, this disagreement in their understanding of Rāmānuja's statements on time had wide-ranging consequences.

But this later debate on time is not understandable without its being examined within the framework of Rāmānuja's key concepts. Both authors developed theories based on Rāmānuja's central concept that the universe of sentient and insentient beings (cidacidvastu) is the body (śarīra) of the supreme brahman, which is the self and Inner Ruler (antaryāmin) of this universe. Whatever forms brahman's body ('sarīra) exists as its mode (prakāra). While transformation (parināma) is accepted for the body, which passes from a causal state (kārañāvasthā) to an effected state (kāryāvasthā), the brahman itself does not change, it remains eternally unimpaired in its perfection. Thus, while the modepossessor (prakārin) and mode (prakāra) are different, they cannot be realized separately (prrthaksiddhyanarha). Together they form a unity. This makes the question of being or nonbeing of the modes redundant, since the difference between the modes, with one being present/manifest but the others not, is a difference between subtle (sūkșma-) and gross states (sthūlāvasthā). When one of these various modes of a modepossessor is manifest and present, the other modes that can specify the same mode-possessor are in a subtle state (sūkșmāvasthā) and not present. The change of the modes (prakāra) is in fact only a transformation of one and the same base through different states (avasthā) or modes (prakāra).

If the focus is then on time, the following questions become relevant. What arguments are used to introduce time into the teaching of the relation between mode (prakāra) and mode-possessor (prakārin)? How does Rāmānuja define time in general, since time is present in only one mode - past, present or future - and the other modes are not present? Is the relation between the modes of time, i.e. time units, reflected in time itself? Does time only qualify (viśeșaṇa)

\footnotetext{
3 Cf. Tattvamuktākalāpa chapter 1 (jaḍadravyasara), verse 65-69; Nyāyasiddhāñjana chapter 1 (jaḍadravyapariccheda), verses 12-24 and commentary (pp. 130-141); Paramatabhanga chapter 2 (acitattattvādhikāra).
} 
something else, i.e. other categories (padārtha)/substances (dravya)? Or is it time itself that is understood as a modepossessor (prakārin), i.e. a substance (dravya) that is temporally transformed by alternating modes (prakāra) such as past (bhūta), present (vartamāna) or future (bhavișyat)? These problems concerning time evoked discussions that developed and challenged the teaching of later Viśiștạadvaitins in various ways.

\section{RĀMĀNUJA'S CRITIQUE OF THE JAINA CONCEPT OF TIME}

As mentioned, Rāmānuja dealt with time in his refutation of Jaina doctrines. In his commentary on Brahmasūtra 2.2.31 (na, ekasminn asambhavāt), which is relevant to our context, he refers to the list of fundamental principles in the Jaina doctrine, that is, the six substances - souls, merit, demerit, body, time and space. Each of these substances has a classification, as for example, souls are bound, perfect or released; merit pervades the world and causes movement; and the all-pervading demerit causes the remnant (sthiti) of the soul. When discussing the six substances as taught by the Jaina, Rāmānuja states that they see time (kâla) as a particular substance which is atomic and is the cause for the different times, namely, "It was, it is, it will be" (abhūd asti bhaviṣyatîti vyavahārahetur aṇurūpo dravyaviśeșah ) [2].

In Rāmānuja's summary of the opponent's view (i.e. the Jaina position), he explains the Jaina view of ontology, which is relevant in this context. According to the Jaina, all mentioned entities (sarvam vastujātaṃ) must be classified as beingness (sattva) or non-beingness (asattva) and, correspondingly, as permanent (nitya) or impermanent (anitya), as well as different (bhinna) or identical (abhinna). The view is defended that any entity can be classified as either substance (dravya) or state (paryāya): Whatever exists as one and permanent can be subsumed under the category of substance; whatever can be said to be the opposite of this belongs to a state (paryāya), which the Jaina renders as the particular state of the substance (cf. Śrībh 309,6: paryāyāś ca dravyasyāvasthāviśeșāh). But to which of these does the Jaina opponent apply his view of difference (bheda) and identity (abheda)? For him, difference (bheda) and identity (abheda) refer to both: to substance (dravya) and its particular state (paryāya). If a substance appears in a particular state, the substance and its particular state are considered to be identical (abheda), while at the same time a particular state (paryāya) is different from all other particular states, which can qualify the substance. Therefore, according to the Jaina, one and the same thing can appear to be manifold. Such manifoldness is enabled by the innumerable states of a substance that are not present when a particular state is present: only one particular state can appear at one time; all other states are different from the particular state that is currently present. For the Jaina, "different" (bhinna) means in this context simultaneously being not present and therefore being "different" from the particular state; "identical" (abhinna) refers to the presence of one particular state.

This is the main point of Rāmānuja's criticism. He does not agree with his opponent that particular states are simultaneously different (bhinna) from each other, if one state is identical (abhinna) with its substance. Therefore he objects to the implied (and for the Jaina, indispensable) simultaneity of identity and difference. In his commentary Rāmānuja explains several times that difference (bheda) and identity (abheda) cannot be connected in a single thing if they are conceptualized as being simultaneous. In this context he refers to his commentary on Brahmasūtra 1.1.4 (tat tu samanvayāt), where he also refuted arguments on difference and identity. Also, there he supported the view that there is no proper reason for the simultaneity of difference and identity in a single base if this is contradictory due to the fact that they exist simultaneously ${ }^{4}[3]$.

Rāmānuja has still more arguments, pointing out another undesirable consequence of the concept of identity (abheda) and difference (bheda) for the relation between substance and particular state. If beingness (sattva) and non-being-ness (asattva) are defined as substance and state, it is impossible for many states to qualify one and the same substance, because in the case of identity (abheda), an eternal being of the substance also implies an eternal beingness (sattva) of the particular state.

But what about the other particular states that are simultaneously different (bhinna) and therefore absent (asattva)? In this case the contradiction arises that if nonbeingness (asattva) of the different particular states is accepted, this would imply the non-beingness of the eternal substance being accepted. Otherwise the identity (abheda) between a substance and a particular state cannot be claimed. Therefore, the beingness of a substance simultaneously with the non-beingness (asattva) of a particular state is again contradictory.

In light of this criticism, Rāmānuja must now face the question of how to explain the inseparable togetherness of alternating states and eternal substance. In his response to the Jaina opponent, Rāmānuja first criticizes the possibility of simultaneity between two contradictory properties, giving the reason:

because in a single entity, beingness, non-beingness, etc., which are contradictory like shadow and heat, are not possible simultaneously ${ }^{5}$ [4].

He continues his criticism by arguing that substance is a separate category (prthagpadārtha). Thus, its simultaneous qualification by different (bhinna) particular states (paryāya) is impossible:

To explain: For something that is qualified by one particular state like beingness, etc., a qualification at the same time by [another] non-beingness, which is contrary to being, is impossible. And the basis of a particular transformation, which is defined as coming into existence

yad api kaiś cid uktam bhedābhedayor virodho na vidyata iti tad ayuktam; na hi śîtoṣnatamaprakāśādivad bhedābhedau ekasmin vastuni samgacchete? Even if by some it is said that no contradiction between difference and identity is known, it is incorrect, because like cool and hot, darkness and light, the difference and identity can not unite in one entity.

ekasmin vastuni astitvanāstitvāder viruddhasya chāyātapavad yugapad asaṃbhavāt. 
and being destroyed, is the impermanence of the substance; and how would it be possible for being eternal, which contradicts impermanence, to be compatible [in one and the same substance]? And how is it possible for being different, which is the basis for a qualifier that contradicts another qualifier, to be compatible in one substance? ${ }^{6}[5]$.

When referring to time, which has the same sort of contradictory states, the decisive point in Rāmānuja's response to the Jaina position is his denial that time, as a substance, can have different particular states as allowed in the Jainas' concept of substance and specific state. Rāmānuja instead argues that time is a qualifier that specifies (other) substances (padārtha). But what concept of time does he have in mind when he gives the following response to the question above?

Since one knows time exclusively (eva) to be the qualifier of a category (padārthaviśeșaṇatayaiva), its separated beingness, its non-beingness, etc. can neither be expressed nor argued. ${ }^{7}$ [6].

One cannot add more to Rāmānuja's words; he opts only for a concept in which time is a specifier (viśeșana) of other substances (dravya). One cannot say that a specifier (viśeșana) of a substance either exists/is present or it doesn't exist. Against the background of Rāmānuja's key concepts mentioned above, his last quoted words ("separated beingness, non-beingness etc." pṛthagastitvanāstitvādayaḥ) become clear: For Rāmānuja, whatever is a specifier is inseparably connected to something that is specified (viśeșya), and whatever is to be specified (viśeșya) is called substance (dravya) or mode-possessor (prakārin). Together they form a unity, and this implies that the specifier (viśeșaṇa) specifies eternally substance/mode-possessor. Nevertheless, it is accepted that there is both a difference (bheda) between mode and mode-possessor, and also inseparable togetherness (aprthaksiddha). Otherwise Rāmānuja cannot say that one substance can be qualified by different specifiers, of whom one is in gross state (sthūlāvasthā) while all others, which belong to a substance, are in a subtle state (sūkșmāvasthā). But identity (abheda) is not required. Rāmānuja therefore compares time with a class characteristic (jāti) like cow-ness, which is realised only as inseparable from an individual.

For those who say: 'There is time; there is no time', it is the same as speaking of the beingness and non-beingness of a class characteristic; class characteristic, etc. are namely to be known as a specifier of the substance. ${ }^{8}[7]$.

The class characteristic (jāti), which always specifies an individual, is to be seen in the context of an inseparable relationship between mode and modifier (prakāra-

tathā hy ekenāstitvādinā 'vasthāviśeșeṇa viśișțasya tadānīm eva na tadviparītanāstitvādiviśișțatvam saṃbhavati.

utpattivināśākhyapariṇāmaviśeșāspadaṃ ca dravyasyānityatvam,

tadviparītam ca nityatvaṃ tasmin kathạ̣ samavaiti.

kālasya padārthaviśeșaṇatayaiva pratīteh, tasya

prthagastitvanāstitvādayo na vaktavyāḥ, na ca parihartavyāḥ.

kālo 'sti nāstīti vyavahāro vyavahartịnāạm

jātyādyastitvanāstitvavyavahāratulyah. jātyādayo hi dravyaviśeșaṇatayaiva pratīyanta. prakāribhāva). By making an analogy between time (kāla) and a class characteristic (jāti), Rāmānuja demonstrates that substances are inseparably connected to time as a specifier (kālaviśeșaṇa). Whatever Rāmānuja has mentioned as a substance can also be specified by time. But it is plainly not said that time specifies as a substance. The question thus arises: Is Rāmānuja thinking of one (eka) time as a specifier, or of different (anekakāla) times that inseparably specify other substances? Was he aware of the problem that time as specifier (viśeșaṇa) in form of time units, needs something to be specified (viśeșya), which can be either time itself or any other category (padārtha)?

One might expect perhaps a more detailed explanation in Rāmānuja's Vedāntadīpa, where he repeats a short passage of his commentary on the Brahmasūtra. But even here he is not more explicit, except by saying that one can understand contradictory states because they take place at different times or by the difference in time (kālabhedena). It is helpful that Rāmānuja mentions in this context that different times of states are related to the power of transformation (parināmaśakti-) of one and the same substance. He elaborates on this in the Vedāntadīpa by drawing an analogy between place and time, saying that for the substance earth, being a pot and being a plate is not possible in the same place. And this is also the case for time:

Similarly, a single Devadatta has a connection with origin and destruction in different times, because by such a degree one entity does not have two different natures but is merely connected by the power of transformation ${ }^{9}[8]$.

But it is still unclear what concept of time Rāmānuja has in mind. Time as a single time, that is, as a substance (dravya) that qualifies something else? Or time only as specifier (viśeșana) of every other substance?

\section{SUDARŚANASŪRI'S VIEW}

We find more information about whether time should be understood as a specifier (viśeșaṇa) or as substance (dravya) in the commentary of Sudarśanasūri (13th c.) on the statements of Rāmānuja in question. He first refers to the contradiction of identity (abheda) and difference (bheda). Repeating Rāmānuja's argument, he demonstrates that in the case of identity (abheda), beingness and non-beingness would characterize an eternal substance at the same time, since presupposing a difference would imply a difference (bheda) between beingness (astitva) and non-beingness (nāstitva), as well as a difference between non-beingness and an eternal substance ${ }^{10}[9]$. In the case of identity (abheda),

\footnotetext{
yathaikasya devadattasyotpattivināśayogitvaṃ kālabhedena. na hy etāvatā vas-tuno dvyātmakatvam, api tu pariṇāmaśaktiyogamātram.

10 ākārabhedābhyupagame ākāre nāstitvādidharmaḥ, dravye tv astitvādidharmaḥ; anabhyupagame tu dravyam evobhayadharmīti virodhạ̣. sattvāsattvanityatvānityatvabhinnatvābhinnatvavirodhạ̣ krameṇopapāditạ̣. kālasya padārthaviśeșaṇatayaiveti. anena kālasyāṇuvanirākaram phalitam. If one accepts the difference of the appearing form, then for the appearing form there is the property of non-beingness; but for the substance there is the property of beingness. But if you don't accept a difference of the appearance, the substance has the property of both [i.e. beingness and nonbeingness].
} 
this would imply the contradiction that beingness and nonbeingness are simultaneous. But how does this relate to time?

Explaining Rāmānuja's above-mentioned reason "since one knows time exclusively to be the qualifier of a category" (kālasya padārthaviśeșaṇatayaiva pratīteḥ), he emphasizes that this refutes the Jaina view of time as being atomic (anutva) since time for him is accepted as omnipresent. In the next sentence Sudarśanasūri says that omnipresence is only possible for one (ekasya) time, and further: time as a substance exists always. Thus non-beingness of time cannot be proved:

The acceptance of many times is incorrect, because we know that many categories exist within one, single time. Beingness as a specification of time as a substance is understood. $^{11}$

He concludes that doubting the non-beingness of time is unreasonable. What Sudarśanasūri means is that time, which is not divided into many times, is one time. Nonetheless it is specified by manifold times. This is, however, more than what Rāmānuja actually says. And the question arises: If time is one, how can it specify all other substances and their respective states? Nevertheless, Sudarśanasūri's view is followed by the school and developed further by Venkatanātha. For the latter, time as an individual substance becomes all-pervading (vibhu) and transforming. Despite this, the concept of time as a specifier was not abandoned. Indeed, Meghanādārisūri explicitly denies that time is a substance and follows Rāmānuja's opinion of time as a specifier (viśeșaṇa) closely.

\section{Time AS A SUbSTANCE (DRAVYA) ACCORDING TO VEṄKAȚANĀTHA}

Venkațanātha is aware of Rāmānuja's discussion. In his Tattvamuktākalāpa he picks up in the first chapter to verse 65 in his auto-commentary, the Sarvārthasiddhi, Rāmānuja's view that separated beingness, non-beingness etc. (pṛthagastitvanāstitvādayah) to which he also referred in the sentence: "Time is; time is not" (kālo 'sti, nāstīti), cannot be accepted.

For those who say there is no time, he mentions the position of the Bauddha's and others (bauddhādibhir), demonstrating that for something that is experienced in every knowledge by all people, non-existence (nāstitvami) cannot be claimed. And in direction to Rāmānuja's Jaina opponent he says that even he cannot prove that beingness of time is something separate from a substance ${ }^{12}[10]$.

In his Sanskrit and Manipravāla works, Venkatanātha accepts time as a separate insentient yet all-pervasive (vibhu) substance that exists in addition to other sentient and insentient substances (such as prakṛti, dharmabhūtajñāna, nityavibhūti, ātman). Time changes due to its having a series of different states (avasthāsantāna).

\footnotetext{
11 anekakālakalpanam ayuktam, ekasmin kāle 'nekapadārthāḥ santīty eva pratīteḥ, kālasya dravyaviśeșaṇatayā 'stitvaṃ pratipannam.

12 na tvayā prthak tadastitvam sādhyam.
}

Venkațanātha applies the transformation he defined for brahman also to time: Just as brahman in the state of cause (kāran̄āvasthā) is itself the cause of the state of effect (kāryāvasthā), in the same way time in the state of cause is the cause of its state as effect. In more detail: if time is in the state of the past, it is the cause for the present state; the present state is the effect of time as a cause being in the past state. In this way time as a substance transforms from one state, i.e. different time units, into another. That this happens is dependent on the Lord himself, who remains unaffected by time $^{13}[11]$.

In Veñkațanātha's teachings, time thus has a central role, since it regulates a series of avasthās in temporal order and makes them understandable due to their being realized as earlier or later. Time as a substance guarantees a recurring regularity. It is not a chaotic flux, in which every determining factor is dissolved, but it is an organized sequence that can be defined by temporal qualifications. Also for the other substance states, time gives them a temporal order.

\section{TIME AS SPECIFIER (VIŚEȘAṆA) ACCORDING TO MEGHANĀDĀRISŪRI}

Meghanādārisūri's understanding of the concept of time is closer to Rāmānuja's depiction of it as a specifier of other categories. In his chapter "definition of time" (kālanirūpaṇa) in his Nayadyumaṇi, his analysis of Rāmānuja's refutation of the Jaina concept of time is meticulous and very subtle. It is also too extensive to be treated here. I will offer a few sentences here merely to indicate his position. Even if time is not a substance, for Meghanādārisūri it is "indestructible" (akșaya), because it has the form of flowing along (pravāharūpena) without beginning or end. The reasons he gives for his view that time is not an eternal substance are the following:

Since, in such a way, time has the form of flowing along (pravāharūpena), speaking and thinking of its undestructibility is correct, as it is the case of thinking and speaking of the indestructibility of the world and as in the quote [from Bhagavadgita 7.6] that starts with the words: "This was indestructible" ${ }^{\text {[12] }}$.

Then Meghanādārisūri names the reasons why time cannot be defined as a substance. For him it is clear, that time is specifying by time units like day and night, something else, i.e. other categories; and therefore it is impossible that time as a substance can qualify other categories.

Due to asserting that time specifies the categories [i.e. other substances], and because one cannot know that one eternal time specifies the other categories, and because one

\footnotetext{
13 And there is not the undesirable consequence that [God] is changed by time if $[\mathrm{He}]$ is in contact with time, because [time] too changes in dependence on Him. na ca kālasaṃyoge kālavikāryatvaprasañgaḥ, tasyāpi tadadhīnavikāratvāt.

14 evaṃrūpakālasya pravāharūpeṇa sthāyitvāt tad etad akṣayam ityādau jagato 'kṣayatvavyavahāravat kālasyākṣayatvavyavahārāś ca
} yuktah. 
can know that exclusively time, which consists in day and night, specifies the categories, the reference that eternal time is a substance does not exist ${ }^{15}$ [13].

\section{CONCLUSION}

Following how time was explained against the background of Rāmānuja's key concepts, we see that the problem of time was not only solved by placing states/modes, which exclude each other, into a series of consecutive states in which one is present in a gross state and others are not, but by its still existing in a subtle state. The question was raised of whether such a transformation presupposes a base/substance for temporal specifiers. While Rāmānuja avoids calling time a substance, what he had in mind may have nevertheless been each specifier being inseparably connected to a substance. The question still remains as to whether such a substance is time itself or other substances. Meghanādārisūri opted for the second possibility. In contrast, Venkațanātha developed his own unique position of time being an underlying, eternal, all-pervasive (vibhu) yet transforming substance.

\section{REFERENCES}

[1] Lakshmi Thathachar, Concepts of Time. Ancient and Modern. New Delhi: Gopson Papers 1996, pp. 68-72.

[2] Vedanta Desikan, Paramatapankkam, T. Nagar: Madras, 1978, Chapter 2, p. 101.

[3] Sri Ramanuja, Sri Bhasya, 2 Vols. [Ubhayavedāntagranthamālā]. Madras, 1967, II, p. 309,6.

[4] Ibid., I, p. 155,9-10.

[5] Ibid., II, p. 309.

[6] Ibid., pp. 309,11-310,3.

[7] Ibid., II, p. 310,4.

[8] Ibid., II, p. 310,5.

[9] Vedanta Deepa of Ramanuja (Reprint). [Ubhaya Vedanta Granthamala]. Nathamuni Street: Madras 1992, p. 63,24-25.

[10] Sudarsana Suri, Śrutaprakāśikā ad Śrībhāṣya ad 2.2.31, II, p. 309.

[11] Veñkaṭanātha, Sarvārthasiddhi and Tattvamuktākalāpa 1.65, p. 207,5.

[12] Venikațanātha, Nyāyasiddhāñjana [Ubhayavedāntagranthamālā]. Madras 1976, p. 482.

[13] Nayadyumaṇiḥ by Meghanādārisūri. Critical ed. with introduction and notes by V. Krishnamacharya, T. Viraraghavacharya. [Madras Government Oriental Studies 141]. Madras 1956, Chapter 10, p. 179, 5-6.

[14] Ibid., p. 179, 6-9.

\footnotetext{
15 tasya padārthaviśeșaṇatvokteh nityakālasya

tadviśeșaṇatvāpratīter ahorātrādyātmakakālasyaiva tadviśeșaṇatvapratīteś ca na nityakāladravyatvābhimatị̣.
} 